\title{
Anatomy and Histology of Reproductive Organ of Male Guinea Pig As a Source of Learning
}

\author{
Elvira Mega Androma*, Laela Umi Khasanah \\ Biology Department, Faculty of Science and Technology, UIN Sunan Kalijaga Yogyakarta \\ Jl. Marsda Adisucipto No 1 Yogyakarta 55281, Indonesia. Tel. +62-274-540971, Fax. +62-274-519739. \\ *Email: elviracantik729@gmail.com
}

\begin{abstract}
Androma E M, Khasanah L U. 2017. Anatomy and Histology of Reproductive Organ of Male Guinea Pig As a Source of Learning. Proc Internat Conf Sci Engin 1: 9-18. This study were aim to (1) describe the anatomical and histological structures of testicular organ, epididymis, vas deferens, accessory glands, and penis in guinea pig (2) develop learning media in the form of histological slides as well as anatomy atlas of male reproductive organs (3) examine the atlas of reproductive organs of male guinea pig as a source of learning. Slide were made using paraffin method with HE staining. The study revealed histological structure of the five guinea pig (Cavia porcellus) accessory glands, namely ampullary glands, seminal vesicles, prostate gland, bulbourethral gland, and preputial gland. In addition, guinea pig penis had a baculum on its base. The results of the student response test showed very good category with the percentage of $90,55 \%$. The readability test had very good value from the subject expert $(95,71 \%)$, media expert $(81,66 \%)$, peer reviewer $(88,07 \%)$ and biology teacher $(81,51 \%)$. Overall, the atlas of the 'Anatomy of Male Reproductive Organs of Guinea Pig' had excellent quality and deserves to be used as a learning resource.
\end{abstract}

Keywords: Anatomy, Histology, Guinea pig, Male Reproductive Organs, Atlas, Learning Media

\section{INTRODUCTION}

The male reproductive system consists of the testes, ductal system, accessory glands, and the penis. The function of the testes are to produce sperm and testosterone. Testosterone is important for spermatogenesis, sexual differentiation during embryonic and fetal development, and gonadotropin regulation. The ductal system and the accessory glands produce secretions and pushing the sperm outward. Secretion also provides nutrients for sperm pass through the reproductive tract. Sperm with the secretions of the ductal system and the accessory glands form the semen and enters the female reproductive tract via penis (Mescher, 2011).

The male reproductive system is one of the hardest subjects to understand because it is complex process of sperm production and how the sperm reaches the urethra passing through several ducts and glands. Difficulties can be overcome by the study of the anatomy and histology of the reproductive organs. Understanding of anatomy and organ histology allow students to understand the complex subject of the reproductive system (Hildebrand, 1995; McLaughlin \& Seaquist, 2008).

Angelina (2013) states that animal tissue is an intricate biological subject to study because it small in size and requires a microscope to observe. Subject cannot be completely understood by students if they do not use media that support the learning process. Learning in high school is done in the classroom, based on textbooks with minimum content. The science curriculum in schools is mostly just a description of words and definitions, with emphasis on benefits and economic applications. Biological content has been abandoned while teachers should provide essential and real science to students (McLaughlin \& Seaquist, 2008).

Anatomical and histological observation is a way of learning that can provide knowledge and experience directly to students (Holil et al, 2001). This hands-on experience will give a deeper understanding of given information or idea (Arsyad, 2011). Direct observation of organs and tissues, could make the concept of the reproductive system more easily understood. Lessons that only rely on textbooks will end on a lack of understanding (Holil et al, 2001).

Research on anatomy and histology of reproductive organs of male guinea pigs as a learning source is rarely done. Learning resources such as histological slides and atlas will help students to understand the subject thoroughly. It is interesting to study the anatomy and histology of reproductive organs of male guinea pigs as learning sources.

\section{MATERIALS AND METHODS}

\section{Time and place}

The study was done for 6 months, from January to July 2017, in Zoology Laboratory of State Islamic University Sunan Kalijaga, Pathology Laboratory of Veterinary Center Wates Yogyakarta and SMA Muhammadiyah 3 Yogyakarta.

\section{Equipments and Materials}

The equipments used in this study were a set of surgical instruments (consisting of surgical scissors, tweezers, razors and scalpels), vial bottles, rulers, DSLR cameras, 
paraffin board, ovens, needles, digital cameras, embedding processors, tissue processors, embedding cassette, staining jar, incubator, warmer slide, microtom, slide and objects glass, masks, gloves, microscopes and computers.

The materials used in this study were HVS paper, chloroform solution, $0.9 \% \mathrm{NaCl}$ saline solution, Bouin solution, ethanol, Hematoxcylin-Eosin dye, albumin, xylol, aquades, entellan, toluene, absolute alcohol, paraffin. The test animals used were adult male guinea pigs.

\section{Procedure}

The procedure in this study consisted of anatomical and histological reproductive studies of male guinea pigs, making biological slide and anatomical atlas, and assess the atlas developed as a learning source.

The first step is an anatomical and histological study of reproductive organ of male guinea pig and making histology slide. Animals were sacrified with chloroform then dissected. Organs of the body that has been dissected are observed, photographed, and sketched. Male reproductive organs include testes, epididymis (caput epididymis, corpus epididymis, and cauda epididymis), vas deferens, ampullary glands, seminal vesicles, prostate glands, bulbourethral glands, and penises found on the animal body are taken and fixed using bouin fixative solutions. Furthermore, the fixed organs are processed for the provision of histological slides by paraffin method.

The second step is the development of anatomical atlas of reproductive organ of male geunia pig. Atlas created using CorelDraw X7, Ms. Publisher, and Ms. Word. Atlas printed with the size of $19.5 \times 26.5 \mathrm{~cm}$ and portrait orientation. The cover used is ivory paper 260 and the contents are 120 mate paper.

The last stage is quality testing of anatomy and histology as a learning resource. Atlas quality testing in this study are subject experts, media experts, peer reviewers, high school biology teachers, and high school students.

\section{Data Analysis}

The results of the assessment are presented in terms of percentage of ideality to determine the final product quality results developed under the following formula (Sudjiono, 2010 in Untari, 2016)

Precentage of ideality $(\mathrm{P})=\frac{\text { assesment result score }}{\text { ideal higest score }} x 100 \%$

Table 1. Percentage scale of product quality.

\begin{tabular}{lll}
\hline Num & Interval & Criteria \\
\hline 1. & $81 \%-100 \%$ & Exelent \\
2. & $61 \%-80 \%$ & Good \\
3. & $41 \%-60 \%$ & Satisfactory \\
4. & $21 \%-40 \%$ & Almost Satisfactory \\
5. & $0 \%-20 \%$ & Unsatisfactory \\
\hline
\end{tabular}

\section{RESULTS AND DISCUSSION}

\section{Anatomy of Male Reproductive Organ of Male Guinea Pig}

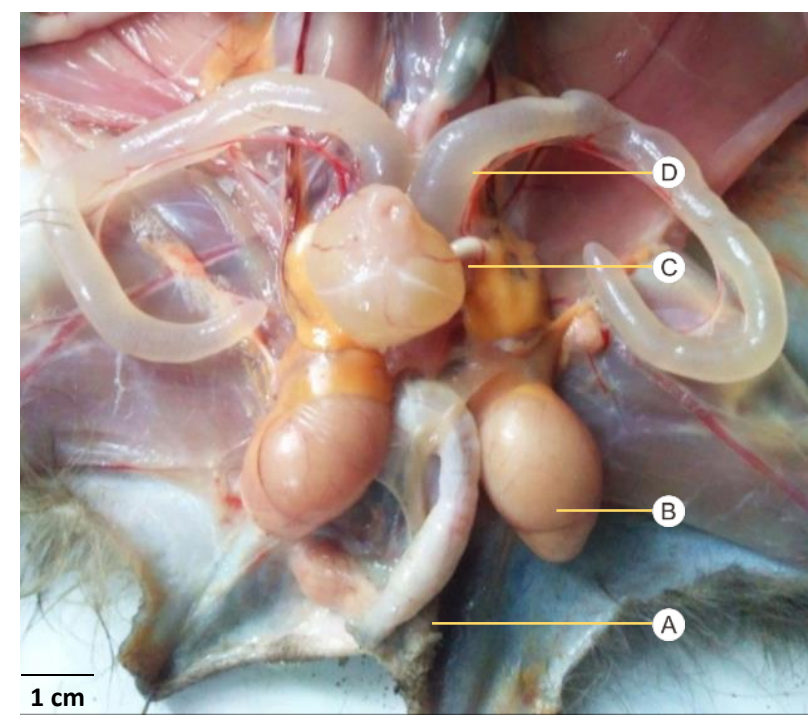

Figure 1. Anatomy of reproductive organ of male guinea pigs (Cavia porcellus) front view. A. Penis, B. Testes, C. Vas deferens, D. Seminal vesicle.

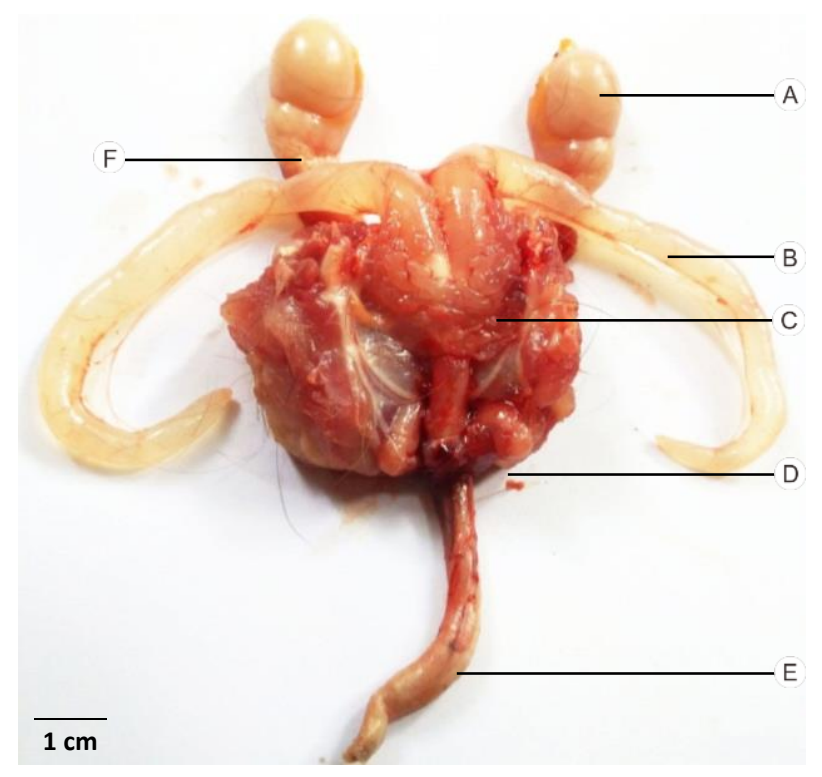

Figure 2. Anatomy of male reproductive organ of male ginea pig (Cavia porcellus) back view. A. Testes, B. Seminal vesicle, C. Prostat Glands D. Bulbourethral glands, E. Penis, F. Epididymis.

In dissection of male reproductive organs of guinea pig, it is observed several organs; testes, epididymis, vas deferens, ampullary gland, seminal vesicles, prostate gland, bulbourethral gland, and penis. The testes are connected by the ducts, the rete ducts, the ductuli eferentes, the epididymis and the vas deferens ducts. This ducts serves to channel the sperm from the testis to the penis.

Testes in Cavia porcellus have a reddish yellow color and there are irregular streaks of blood vessels. From the testis emerge duct that called ductus 
epididymis. The epididymis is shaped like a long winding pipe that has three parts: the top (caput epididymis), the middle (the corpus epididymis), and the lower end which is the boundary between the epididymis and the vas deferens called cauda epididymis.

The testes of guinea pig is located in the scrotum between the two hind limbs and the penis is between the two testicles just like any other mammals. The scrotum is a sac composed of skin and muscles that wrap the testes. The main function of the scrotum is maintain the testes temperature to $1-8{ }^{\circ} \mathrm{C}$ cooler than the temperature of the body core. In addition, the scrotum also serves to support and protect the testes and epididymis and maintain a lower temperature than the body temperature that will be required for the process of spermatogenesis.

Male guinea pig have five sex glands including the ampullary glands, seminal vesicles, prostate glands, bulbourethral glands, and preputial glands. The ampulla gland is at the end of the enlarged vas deferens. Guinea pigs have a pair of long clear big yellowish seminal vesicles. This is a distinctive feature of guinea pigs, because the average mammal has short, twisty, and small one.

Under the seminal vesicles there is a light brown gland called the prostate gland, this gland encircles the urethra (Figure 2). Below the prostate gland there are two small round glands called bulbourethral glands. In the distal part of penis, the preputial gland located. It is in the skin part of the distal penis fold, consists of sebaceous secretory cells. To get the prostate gland and bulbouretra gland, dissection should be done through the anus because the location of these two glands is anchored above the anus.

The penis of guinea pig (Cavia porcellus) has a difference with the penis in other mammals, because in the guinea pig penis there is a baculum or penile cartilage (figure 15) located at the base of the penis. The guinea pig penis looks reddish white.

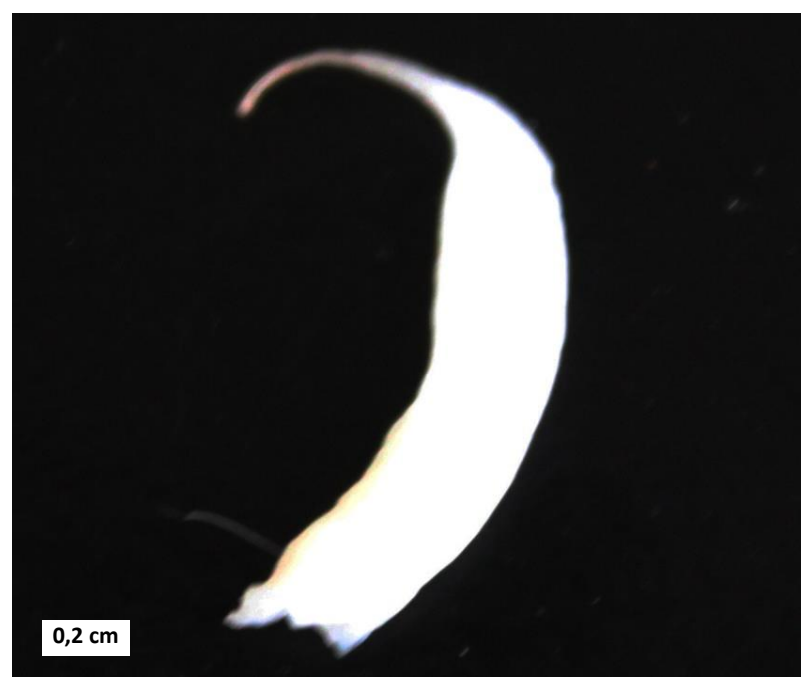

Figure 3. Anatomy of guinea pig's baculum in the distal of penis.
According to the literature, the anatomy of a mouse penis and several other Rodentia are composed of proximal bodies and distal glans. It is composesed by the corpus cavernosum, corpus spongiosum, and the urethra of the penis. The os penis consists of proximal and distal elements. The proximal element contains hyaline cartilage with proximal growth and a distal bone consisting of fibrocartilago that hardens after puberty. In conjunction with the hydrostatic mechanism, these skeletal elements are likely to provide the necessary stiffness for copulation (Simmons \& Jones, 2007 in Phadmancanty, 2013).

\section{Histology of Male Reproductive Organ of Male Guinea Pig}

Histological slides were made using Hematoxylin-Eosin (H-E) dyes. This dye is a deferential dye to distinguish between the plasma membrane and the cell nucleus. The histological picture of the male reproductive organ of Cavia porcellus with Hematoxylin-Eosin staining (H-E), indicates that the cytoplasm will be pink, while the cell nucleus will be colored in purple. The HematoxylinEosin (HE) dye is a common histological stain used in histology that can show more cells/tissues compared to other dyes. The analysis of each slide drawing image is as follows:

\section{Testis}

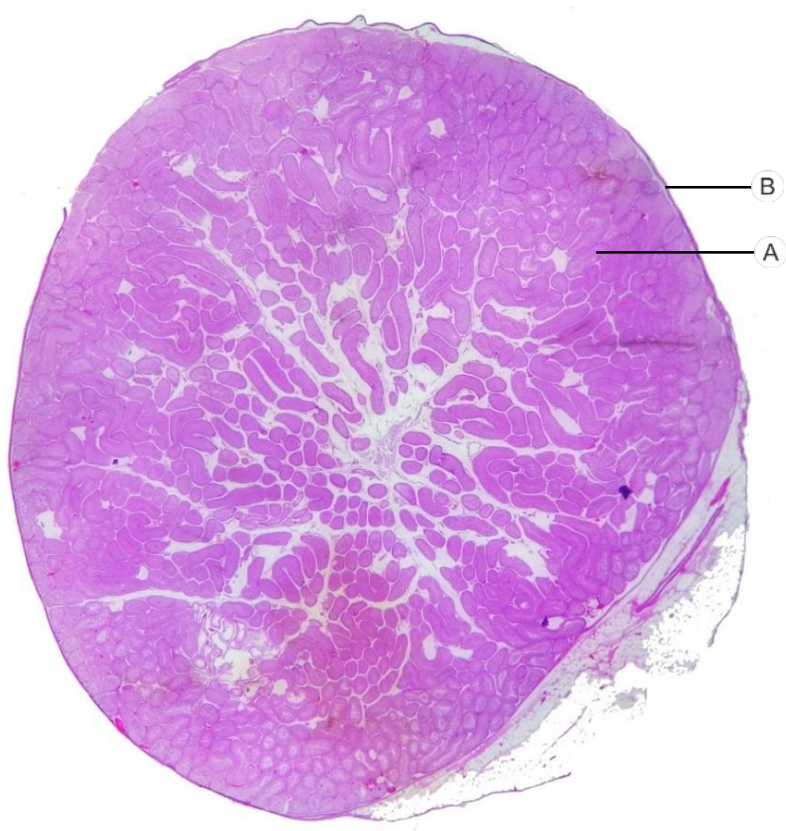

Figure 4. Testes og Guinia pig (Cavia porcellus). A. Seminiferous tubules, B. Tunica albuginea. H\&E. 10x.

Testes are the most important reproductive organs that composed of seminiferous tubules to produce sperm. In addition, the testes also function to produce testosterone. The testes are wrapped by two layers: tunica vaginalis (outer layer) and tunica albuginea (layer under tunica vaginalis). 


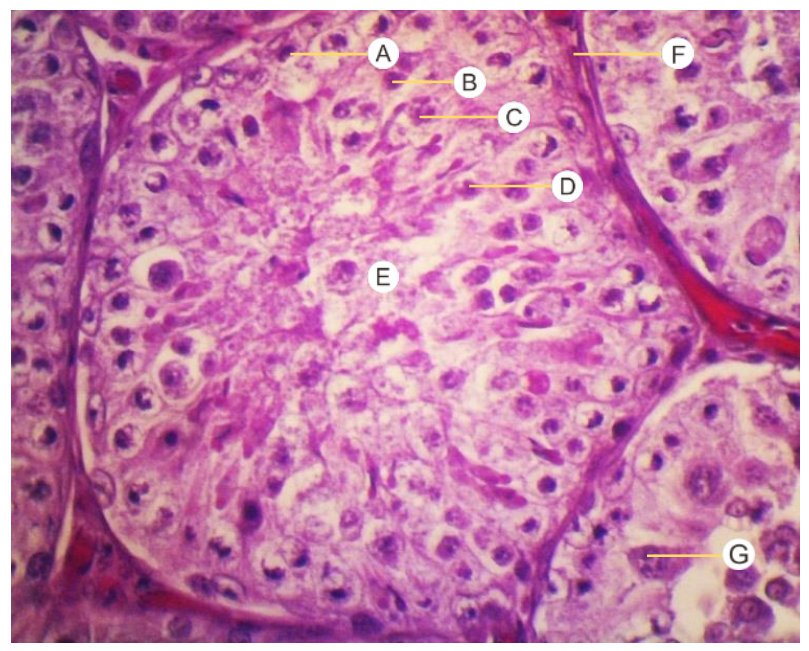

Figure 5. Seminiferous tubules of guinea pigs (Cavia porcellus). A. Spermatogonium, B. Spermatosit, C. Spermatid, D. Sperma, E. lument, F. flat mioid cell, G. Sertoli cell. H\&E. 400x.

The seminiferous tubule is a winding tube that forms a scroll in a lobule. Among the seminiferous tubules there are a layer of germinal cells and of connective tissue and Leydig cells. Leydig cells act as a producer of testosterone. The tubular epithelium of seminiferous consists of two types of cells namely Sertoli cells or support cells and germinative (spermatogenic) cells. The spermatogenic derivative cells are spread in 4 to 8 layers that occupy the space between the basal lamina and the tubular lumen. These cells divide several times that eventually differentiate to produce sperm. The process from beginning untill end is called spermatogenesis.

\section{Ductal System}

\section{Rete testes}

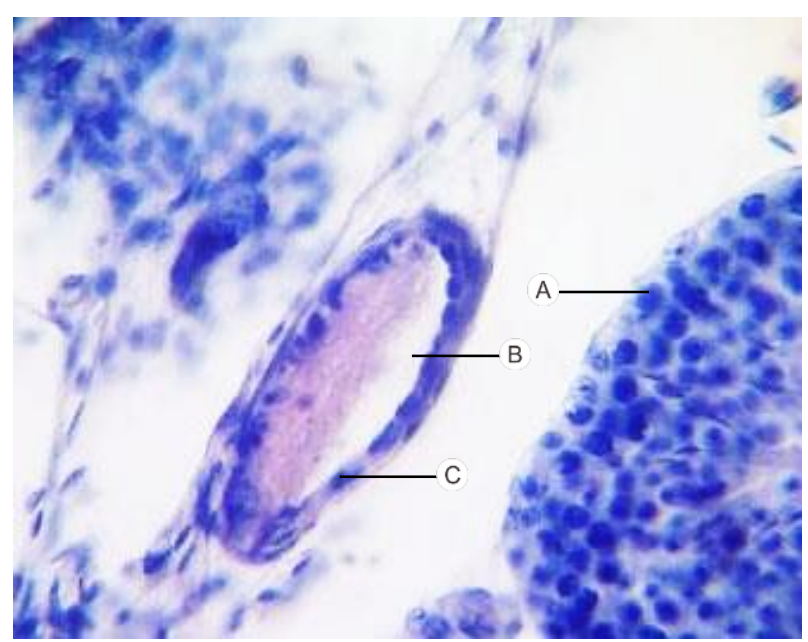

Figure 6. Rete testis of male guinea pig (Cavia porcellus). A. Seminiferous tubule, B. rete testis, C. simplex squamous epithelium. H\&E. 400x.

The seminiferous tubules that approach the mediastinal testes merge become rectus tubules. Some rectus tubules enter the mediastinum and relate to one another, thus forming a web called rete testis. Rete testis are duct that enter the epididymal caput called ductuli eferentes.

Rete testis is located in the mediastinum region and the walls are covered by a simple squamous epithelium. Then from the rete testes, it will continue into the ductuli eferentes, which is the duct that connects the rete testes with the epididymis. The ductuli eferentes ducts are lined with two types of cells: cylindrical columns (stereocilia, movable cilia) and cuboid cells that produce fluids.

\section{Ductuli Eferentes}

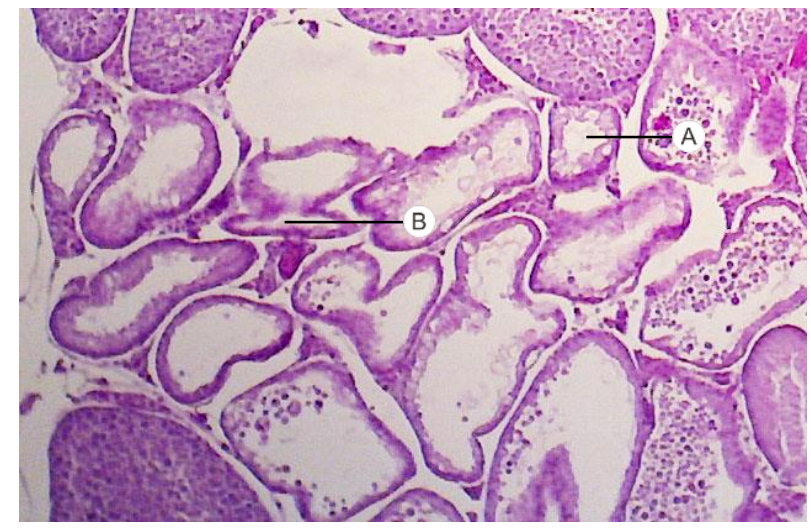

Figure 7. Ductuli eferentes of male guinea pigs (Cavia porcellus). A ductuli eferentes, B. rete testis. H\&E. 1000x.

At the cranial of the mediastinum testis there are about 6-12 ducts called: Ductuli eferentes testis. The duct is initially straight but after entering the epididymis it becomes twisted into a spiral. The entry region is known as the vascular cone that faces the testis and is the epididymal head. Ductuli eferentes have a cylindrical epithelium in line with two kinds of cells, namely: basilia cells and cells without cilia with many of secretions in them, these cells exhibit secretory activity. The epithelium lies on the basement membrane. The secretions of these cells use in the maturation process of sperm in the epididymis

\section{Epididimis}

Three parts of epididymis are marked of the histology structure, namely on the epithelium and the lumen. High columnar epithelium is a character of caput epididymis, medium columnar size is of the corpus, and low columnar is of cauda.

The duct in the epididymis has a different columnar cell type on each part. The function of stratified columnar columnous epithelial cells with stereosilia is to regulate the state of the environment for sperm maturation. The modification or low height of the columner cells in the epididymal duct has an influence on sperm maturity and the locomosi system of sperm (Zaki (2013) in Anisatuzzahro, 2015). 

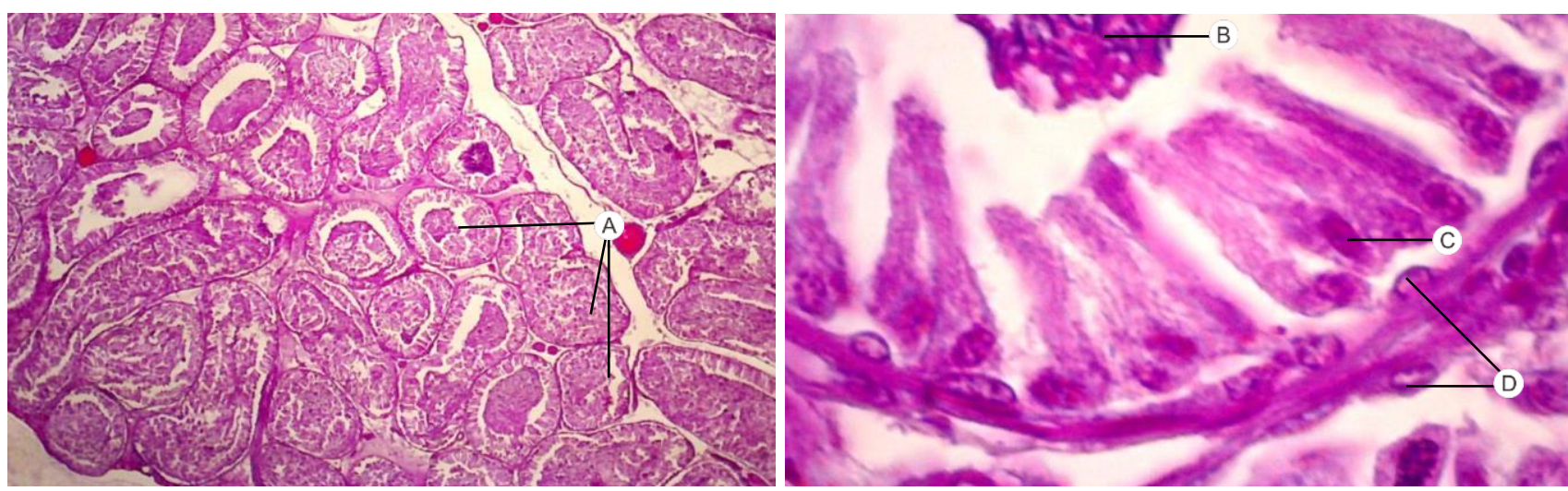

Figure 8. Caput epididymis of guinea pig (Cavia porcellus). A. Ductus epididymis, B. Sperm, C. Epithelium, D. Smooth muscle cells. H\&E. above 40x, under 1000x.
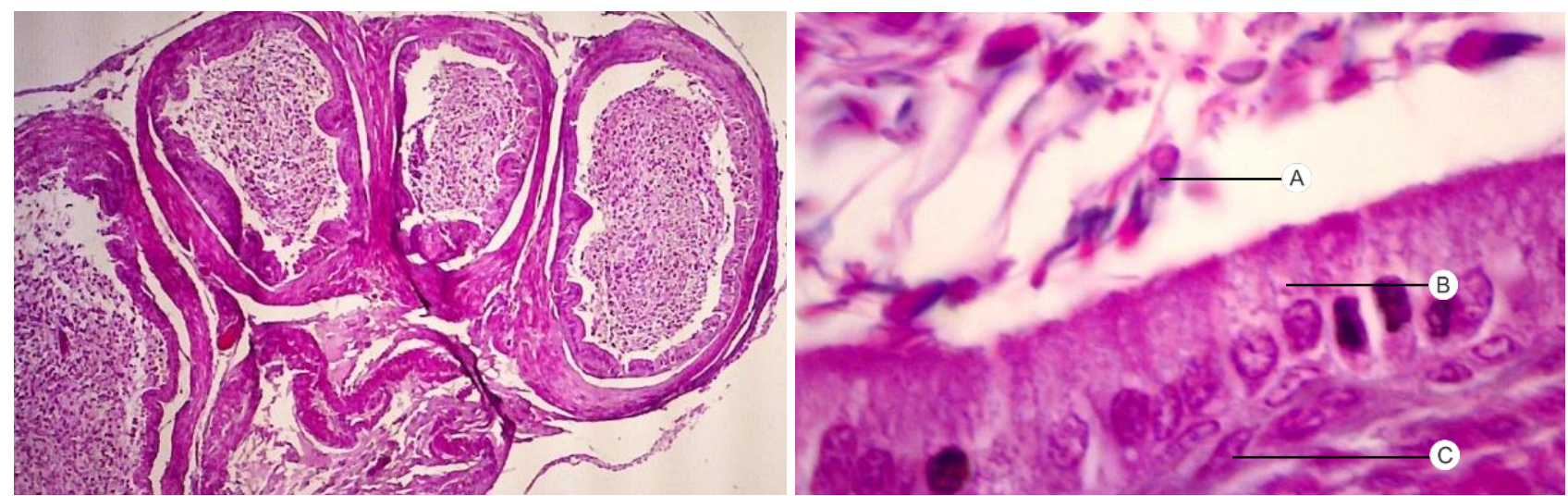

Figure 9. Epepididymis corpus of male guinea pig (Cavia porcellus). A. Sperm, B. Epithelium, C. Smooth muscle cell. H\&E. left 40x, right 1000x.
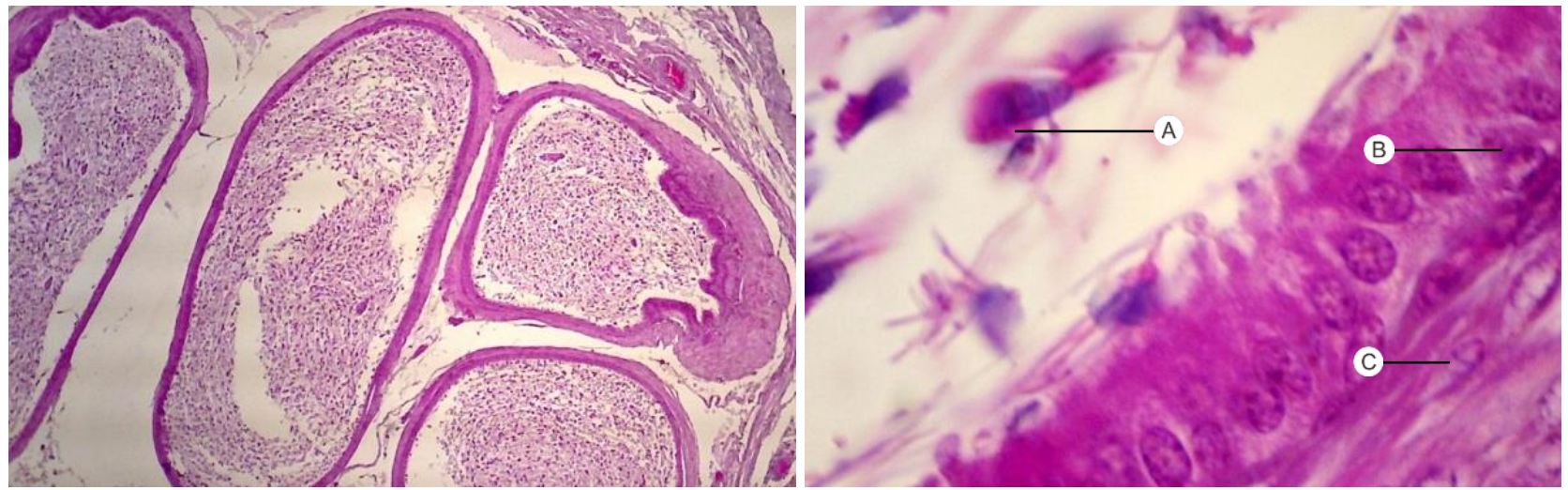

Figure 10. Epididymis cauda of guinea pigs (Cavia porcellus). A. Sperm, B. Epithelium, C. Smooth muscle cell. H\&E. left 40x, right 1000x.

Three parts of epididymis are marked of the histology structure, namely on the epithelium and the lumen. High columnar epithelium is a character of caput epididymis, medium columnar size is of the corpus, and low columnar is of cauda.

The duct in the epididymis has a different columnar cell type on each part. The function of stratified columnar columnous epithelial cells with stereosilia is to regulate the state of the environment for sperm maturation. The modification or low height of the columner cells in the epididymal duct has an influence on sperm maturity and the locomosi system of sperm (Zaki (2013) in Anisatuzzahro, 2015). 


\section{Vas deferens}

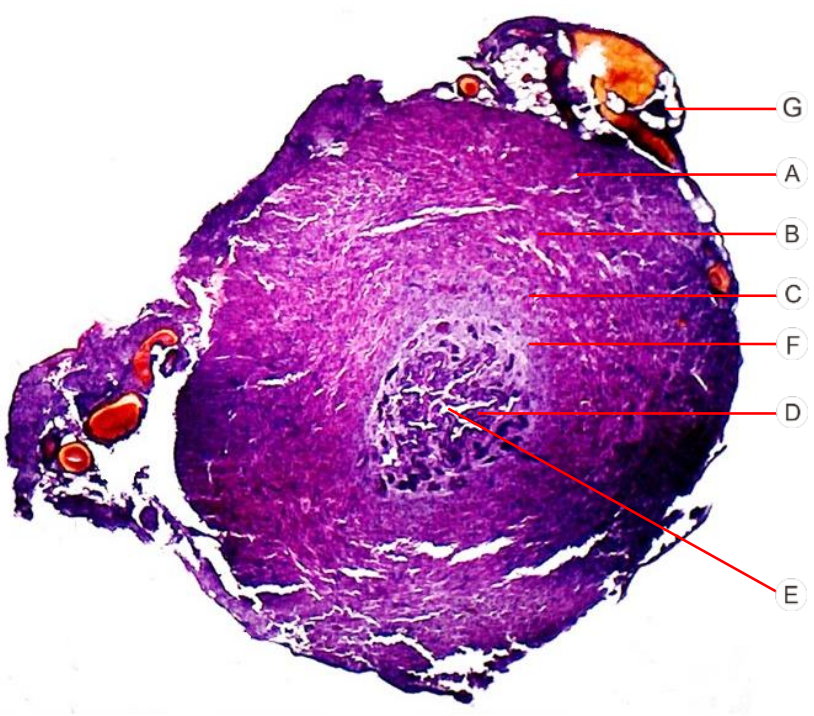

Figure 11. Vas deferens marmut (Cavia porcellus). A. External longitudinal layer, B. Circular layer, C. longitudinal layer, D. Epitel, E. Lumen, F. Lamina propria, G. Sdventitia eksternal. H\&E. 100x.

The vas deferens serves as an important sperm storage because the relatively inactive sperm and their metabolic state are also low, sperm can be stored in the vas deferens for several days even if they do not get the nutrient from the blood and only get the nutrients from the simple sugars that can secreted by the tubules.

Near the end, the vas deferens widened to form a coil called the ampulla. Epithelium of vas deferens is a columnar epithelium and most of its column have stereosilia. Among the thin layers of epithelium and lamina propria there is a subtle lamina basalis with many elastin fibers.

\section{Accessory Glands}

\section{Ampullary Gland}

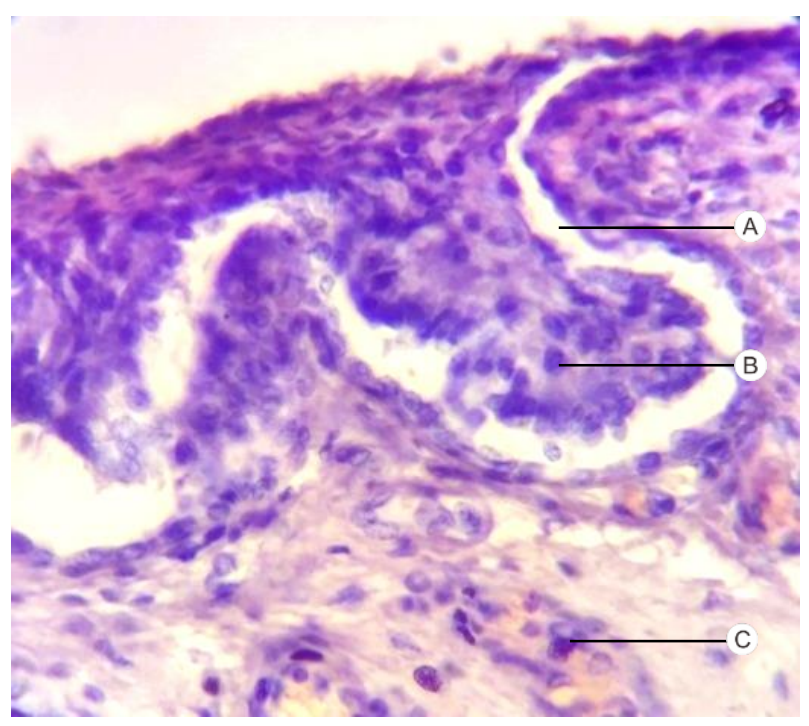

Figure 12. Ampulla gland of male Guinea pig (Cavia porcellus). A. Lumen, B. Basal cells, C. Muscular tunica. H\&E. 400x.
Ampullary glands are a pair of glandular accessory located at the end of the vas deferens. The ampulla glands produce lipids and glycogen and are distinguished from the prostate as they are surrounded by dense muscular fibrous stroma. In addition, the ampullary gland consists of the tubuloalveolar secretory gland, muscular tunica, secretions, loose connective tissue, interlobular septum, cytoplasm, basal cell, lumen and epithelial cells. The ampulla lumen is larger than the vas deferens.

\section{Seminal Vesicle}

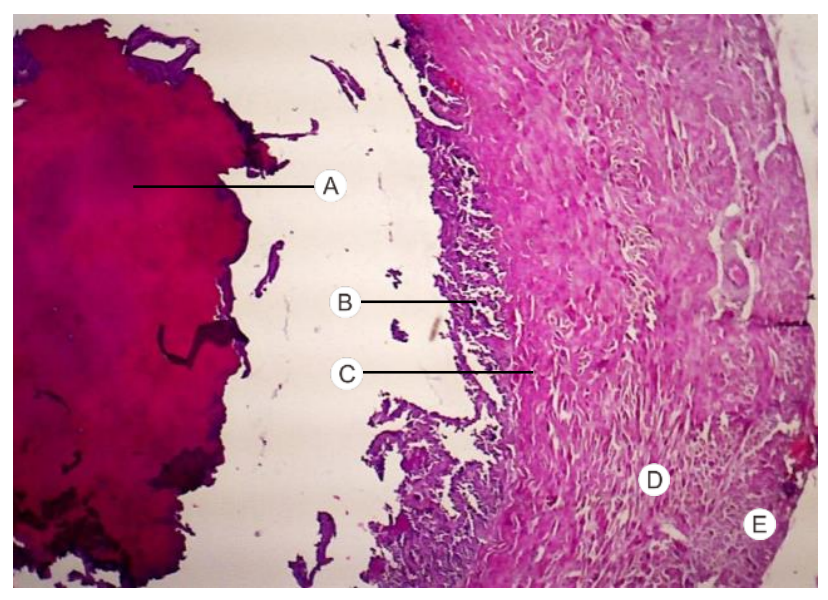

Figure 13. Seminal vesicle of guinea pig (Cavia porcellus). (A) Secret in the lumen, (B) epithelium, (C) lamina popria, (D) circular smooth muscle layer, (E) longiitudinal smooth muscle layer. H\&E. 100x.

Seminal vesicles are produced fructose that serve as a major energy source for sperm released. In addition, the seminal vesicles also secrete prostaglandins that stimulate smooth muscle contraction in male and female reproduction, so that sperm is easily transferred to the oviduct for fertilization. It made up more than half of the semen, which help to push the sperm into the urethra and also dilutes the thick sperm mass so that sperm motility is increase (Akbar, 2010).

The typical mucosa shows a large number of thin that fill most of the lumen. These folds are coated by a multilevel columnar epithelial layer that has many secretory granules. Lamina propria contains elastin fibers and is surrounded by smooth muscle with a deep circle and external longitudinal layer

\section{Prostate Gland}

The prostate gland is a solid organ that surrounds the urethra below the bladder. The prostate is a bunch of 3050 branching tubuloalveolar glands, all of which are surrounded by solid fibromuscular stromas coated by a hoop. Prostate gland is composed of concentric layers around the urethra: the internal lining of the mucous gland, the intermediate layer of the submucosal gland, and the peripheral lining with the prostate's main gland. The prostate has three zones corresponding to the glandular layer: 1) the transition zone occupies about $5 \%$ the volume of the prostate, surrounds the prostatica 
urethra, and has mucous glands that empty directly into the urethra; 2) the central zone occupies $25 \%$ of the volume of the prostate gland and has submucosal glands with longer ducts; 3 ) the peripheral zone occupies about $70 \%$ of the prostate gland and has a major gland with a longer duct. These area glands are the most likely site of inflammation and cancer (Mescher, 2011).

The prostate tubuloalveolar gland is formed by a cylindrical epithelial layer. The gland of the prostate contains various glycoproteins and enzymes and stores this sap to be removed during ejaculation. A large number of fibromuscular stromas surround the gland. The prostate is surrounded by fibroelastic loops. Like the seminal vesicles, the structure and function of the prostate depend on testosterone levels.

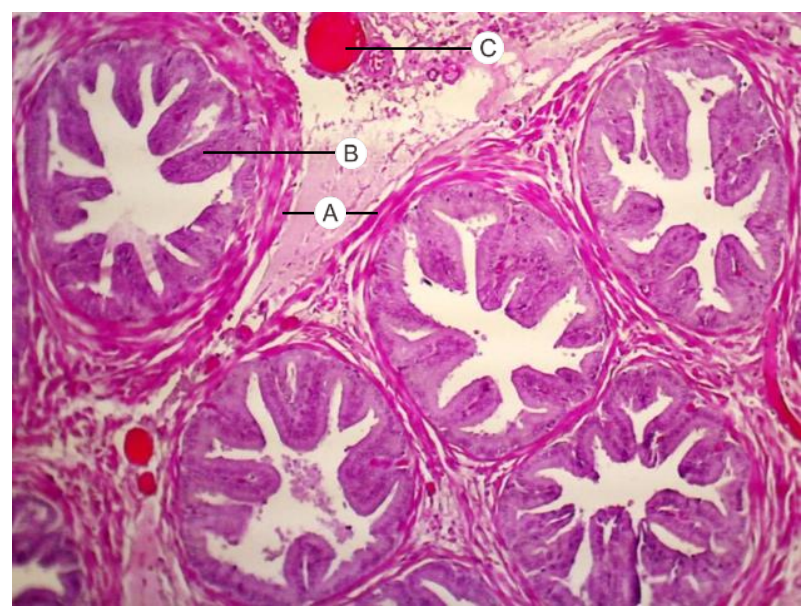

Figure 14. Prostate gland of male guinea pig (Cavia porcellus). A. Alveoli glands epithelium, B. Smooth muscle in stroma, C. Blood vessel. H\&E. 100x

\section{Bulbourethral Gland}

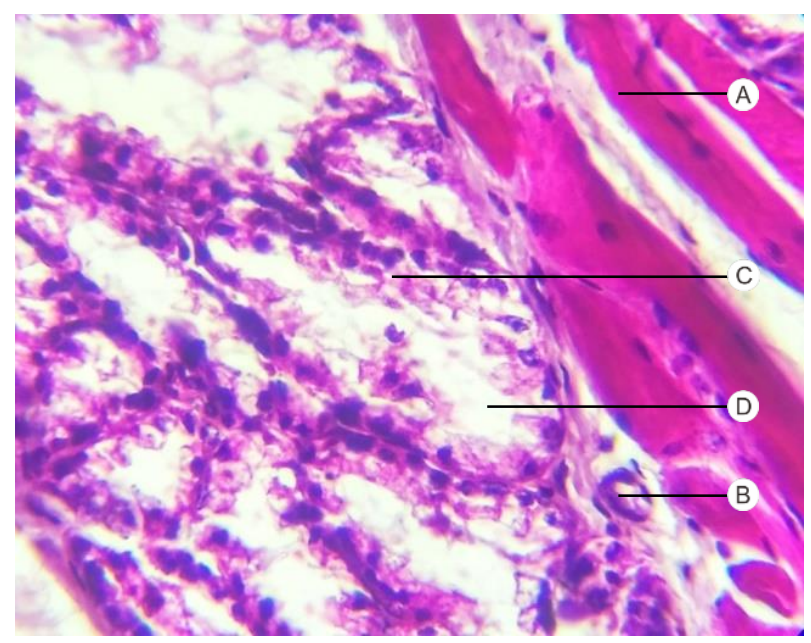

Figure 15. Bulbourethra gland of male guinea pigs (Cavia porcellus). A. Longitudinal skeletal muscle tissue, B. Connective tissue capsule, C. Septum connective tissue, D. Excretory duct. H\&E. 400x.

The bulbourethral gland (Cowper's gland) is located in the urogenital diaphragm and empties into the proximal portion of the urethra of the penis and amounts to a pair. Each gland has a lobule with a tubuloalveolar secretory unit. The septa between the lobules contains smooth muscle. During an erection, this gland releases a mucous-like clear secretion and contains small carbohydrates that envelop and lubricate the urethra. Bulbourethral gland is wrapped by a skeleton muscle tissue capsule and smooth muscle.

\section{Preputial Glands}

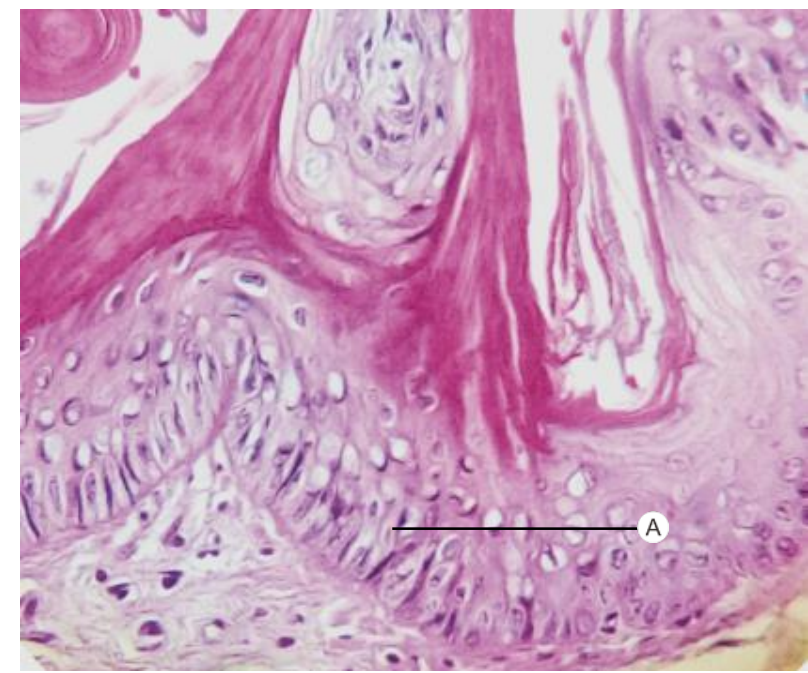

Figure 16. preputial gland (Cavia porcellus). A. Sebaceous secretory gland. H\&E. 400x.

The preputial gland is found on the distal skin of the penis. In immature males this gland is still not functioning properly. The preputial glands during adulthood will produce a secretion that will serve as a lubricant during copulation. The secretions produced by the preputial glands will come out through the skin. This gland is composed of sebaceous secretory cells that are oval-shaped, arranged in a row to form a curve and then at the top there are muscles (Phadmancanty et al, 2013).

\section{Penis}

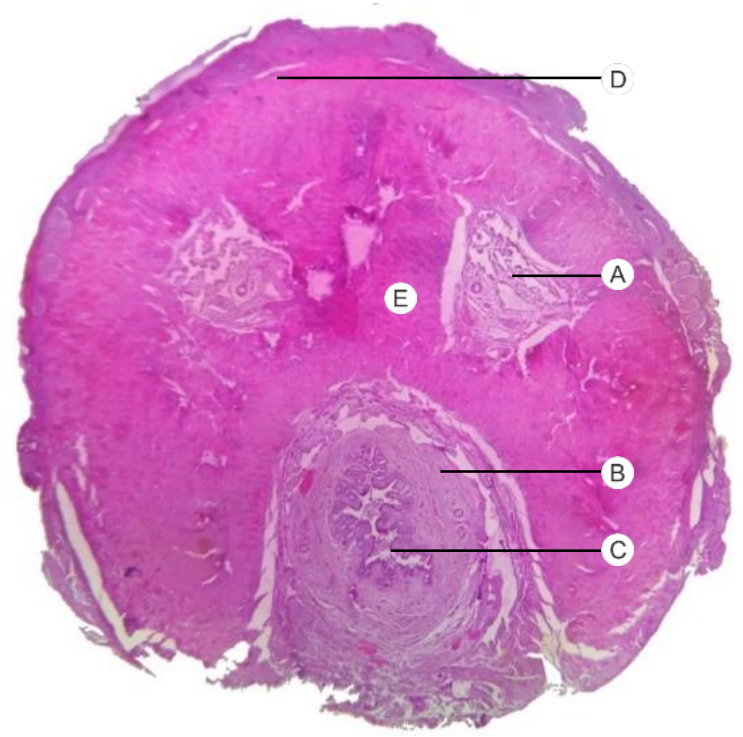

Figure 17. Penis of male guinea pig (Cavia porcellus). A. Cavernosum Corpus, B. Spongiosum corpus, C. Urethra, D. Tunica albuginea, E. Septum median. H\&E. 10x. 
The main components of the penis are the three cylindrical and erectile tissues, and the skin-wrapped urine of the penis (Mescher, 2011). Two of these cylinders are a pair cavernosum corpus located adjacent to the dorsal, while the one on the ventral side of the penis is the spongiosum corpus surrounding the urethra. The three erectile tissues are surrounded by solid fibrous albuginea tunica.

The cavernosum corpus is wrapped by a solid connective tissue layer that is tunica albuginea. The cavernosum corpus and the spongiosum corpus consist of erectile tissue, which contain large amounts of cavernous space of the veins lined with endothelial cells and separated by trabeculae consisting of connective tissue fibers and smooth muscle cells. The sheath (tunica albuginea) in the spongiosum corpus is thinner than the corpus cavernosum. Trabecula of spongiosum corpus also thinner and more elastic than those found in the cavernosum corpus (Leeson, 1989).

\section{Baculum (Cartilage of Penis)}

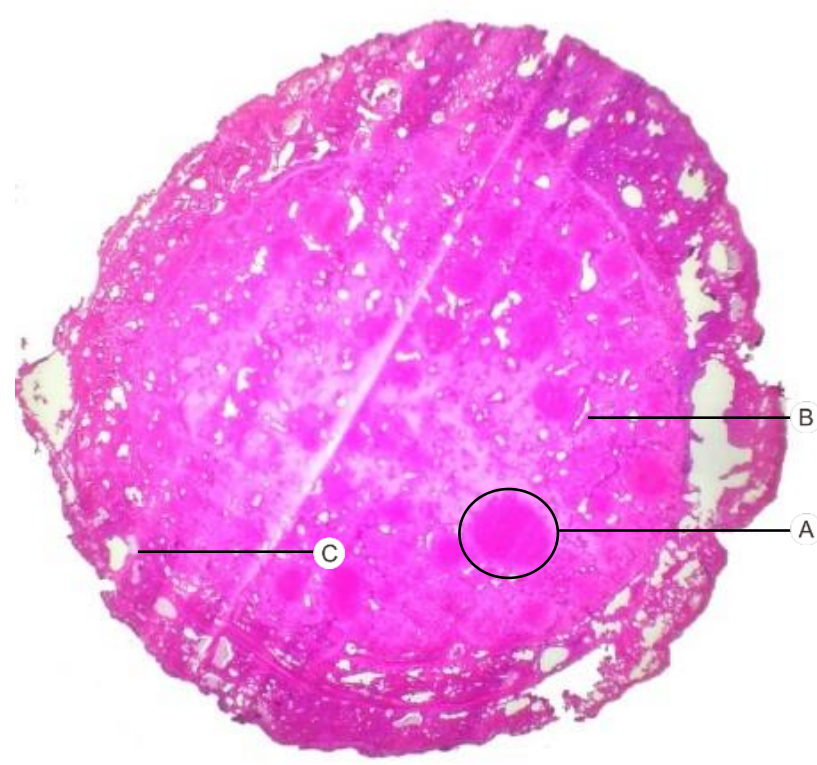

Figure 18. Baculum (cartilage of penis) of male guinea pig (Cavia porcellus). A. Havers system, B. Havers Canals, C. Canaliculi. H\&E. 10x.

Baculum or cartilage in the guinea pigs penis has a structure similar to that of solid bone, i.e., havers system, channel havers, and canaliculi. In figure 18 there is a white streak on the histology incision that is due to imperfect cutting. In addition, the baculum did not undergo the decalcification process using acidic solution, so it is still hard when cutting was done.

\section{Making of Atlas of Anatomy and Histology of Male Reproductive Organ of Male Guinea Pig}

The anatomical and histological atlas were made using Microsoft publisher 2010 and Coreldraw X5 applications. The production stage includes: data collection of images, capturing images using an optical microscope; atlas design using Microsoft publisher application; while the cover is designed using Coreldraw.

The atlas of 'Anatomy of Reproductive Male Male Reproduction Organs' is a customized size $19.5 \mathrm{~cm} \mathrm{x}$ $26.5 \mathrm{~cm}$. This size is chosen because it is very optimum to the reader. The image is obviously not too big and not too small to display one image in a single page. The front cover is the title of the book, the author's name, the anatomical and histological picture of the book's contents and the logo of UIN Sunan Kalijaga. While in the back cover there were title of the book, author's name and a synopsis that describes the contents of the book. Cover of atlas is dominated by purple color because the histologal pictures are dominated by purple and dop laminated for not to reflex the light.

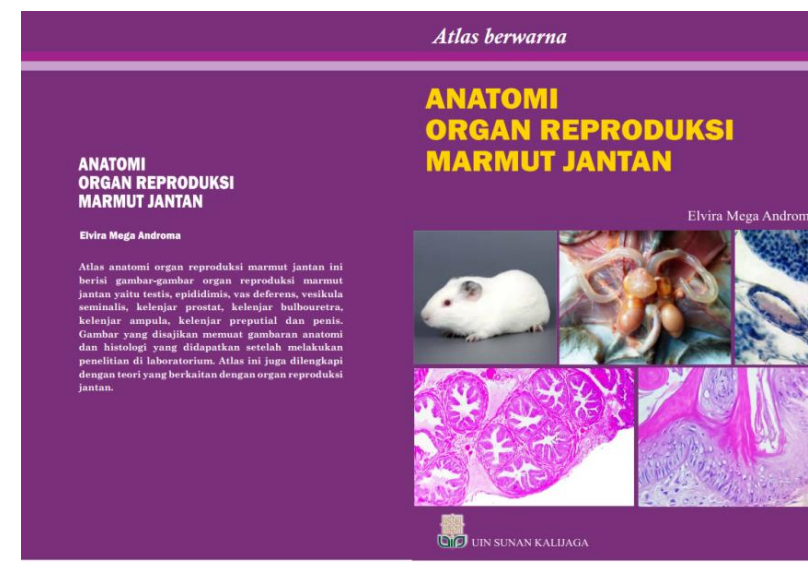

Figure 19. Cover of atlas.

The atlas contains all the important elements of anatomy and histology of reproduction of male guinea pig. It included material posts, drawings, sketches, and tables. On the contents of the atlas there was a table that is an introduction to explain the description and function of all histological images, so readers can easily study this atlas. By studying the tables on this atlas, the reader will know briefly the whole reproductive organs of male guinea pigs early. This will increase the reader's interest to open the next page and as an introduction that covers the entire contents of the atlas in a single page.

In the anatomical picture, there are some organs that are not visible from the front side, so there are photos from the back side. In addition, sketch drawing facilitate the reader in conveying the reproductive organ location of male guinea pig. So the reader will understand where the existing organs are in the reproductive system of male guinea pigs. After real photos, sketch images, then there is a histology image showing the tissue of every male reproductive organ of male guinea pig. Explaining anatomical material is not enough to show only real photos, but requires sketches to clarify the existence of every male reproductive organ of male guinea pig. Given cell/tissue is selected with black pointer line style on the part of the organ and directly written the name of the organ. This style was chosen because readers will more easily understand when viewing the image and 
directly know the name of organ, compare to that with symbole and the explanation is on the other part. Direct explanation of organ part is more effective because the reader does not need to divert the view repeatedly to match the image code with the description.

\section{Assessment of Anatomical Atlas of Male Reproductiv Organ of Male Guinea Pig as a Learning Source}

Table 2. Assesment percentage.

\begin{tabular}{lll}
\hline Assessor & Assesment percentage (\%) & Quality \\
\hline Subject expert & 95,71 & Exelent \\
Media expert & 81,67 & Exelent \\
Peer reviewer & 88,07 & Exelent \\
Biology teacher & 83,51 & Exelent \\
Student & 90,55 & Exelent \\
\hline
\end{tabular}

The quality of the atlas is assessed by subject expert, media expert, peer reviewer, biology teachers, and student. Assessment aspect of each of the expert is different. The subject expert assess aspects of material feasibility and linguistic aspect. Media experts assess aspects of design and layout. Peer reviewers assess the material aspects, aspects of appearance and layout, and linguistic aspects. The biology teacher assess aspects of material feasibility, the linguistic aspect and the aspect of the implementation. Students assess the aspect of material feasibility, linguistic aspects, display aspects, and aspects of the implementation. Assessment uses a questionnaire and a suggestion box for atlas revision. The results of student response test showed very good category with the percentage of $90,55 \%$. The readability test had very good value from the subject expert $(95,71 \%)$, media expert $(81,66 \%)$, peer reviewer $(88,07 \%)$ and biology teacher $(81,51 \%)$. Overall, the atlas of the 'Anatomy of Male Reproductive Organs of Guinea Pig' had excellent quality and deserves to be used as a learning resource.

\section{CONCLUSIONS}

1. Based on observations of macroscopic and microscopic anatomy of the male reproductive organs of male guinea pigs (Cavia porcellus), we found testes, penis, ductal system, and five accessory glands. The ductal system consists of testicular rete, ductuli efferentes, epididymis, and vas deferens. The accessories glands of the male reproductive organs consist of the ampullary glands, the seminal vesicles, the prostate gland, the bulbourethral gland, and the preputial gland. In addition, the guinea pig penis has a cartilage of penis or baculum.

2. Research has succeeded in creating histological slides and colored atlas of 'Anatomy of Male Reproductive Organ of Male Marmot.

3. The results of student response test showed very good category with the percentage of $90,55 \%$. The readability test had very good value from the subject expert $(95,71 \%)$, media expert $(81,66 \%)$, peer reviewer $(88,07 \%)$ and biology teacher $(81,51 \%)$. Overall, the atlas of the 'Anatomy of Male Reproductive Organs of Guinea Pig' had excellent quality and deserves to be used as a learning resource.

\section{REFERENCES}

Akbar, Budhi. 2010. Tumbuhan dengan Kandungan Senyawa Aktif yang Berpotensi sebagai Bahan Antifertilitas. Jakarta: Adabia Press.

Angelina, G. 2013. Analisis Kelayakan Multimedia Interaktif Biologi SMA pada Materi Sel, Jaringan Tumbuhan, Jaringan Hewan, Sistem Gerak Manusia, dan Siatem Peredaran Darah. (skripsi). Bandung: UPI.

Anisatuzzahro, 2015. Kajian Anatomi Organ Reproduksi Jantan Codot Besar. (Skripsi). Yogyakarta: UIN Sunan Kalijaga.

Arsyad, A. 2011. Media Pembelajaran. Jakarta: PT Raja Grafindo Persada.

Bergman, Ronald A., Afifi, Adel K. 2002. Atlas of Human Anatomy. Germany: The University of Lowa.

Bevelander, G. \& Ramaley, Y.A. 1988. Dasar-Dasar Histologi. Jakarta: Penerbit Erlangga.

Campbell, N. A., J.B. Reece, \& L.G. Mitchell. 2004. Biologi. Jilid 1. Terj. dari Biology, oleh W. Manalu. Jakarta: Penerbit Erlangga.

Castle M., Cleveland C., Gordon D., Jones L., Zelinsky M., Winter P., Chang J., Mitchell E. S., Coutifaris C., Shuda J., Mainigi M., Bartolomei M., Woodruff T.K., 2016. Reproduktive Science for High School Student: A Shared Curriculum Model to Enhance Student Succes. Biology of Reproduction. 95 (1): 28, 1-4.

Conti et al. 2004. Atlas of Laboratory Mouse Histology. America. : The University of Texas.

Cook. Margaret, J. 1965. The Anatomy of the Laboratory Mouse. England: Academic Press.

Daryanto. 2013. Media Pembelajaran. Yogyakarta: Gava Media.

Depdikbud, Indonesia. 2005. Kamus Besar Bahasa Indonesia. Jakarta: Balai Pustaka.

Eroschenko V. P. 2002. Atlas Histology Difiore. Jakarta: EGC.

Geneser, Finn. 1994. Buku Teks Histologi. Jilid 2. Jakarta: Binarupa Aksara.

Hafez, E.S.E and Prasad. 1976. Functional Aspects of Epididimis Saint Louis: The C.V. Mosby Company.

Harjana, Tri. 2011. Buku Ajar Histologi. Yogyakarta: Universitas Negeri Yogyakarta.

Hildebrand, Milton. 1995. Analysis of Vertebrate Structure. America: The United States of America.

Holil, K., Rofiq, A., Wahyuni, Sri., 2001. Pembuatan Preparat sebagai Media Pendidikan pada Studi Biologi. Malang: Jurnal Dedikasi 1(1): 136-139.

Junqueira, L.C., Carneiro, J. and Kelly, R.O. 1997. Histologi Dasar. Terj. dari Basic Histology. Oleh Tambayong Jan. Jakarta: Penerbit Buku Kedoktean EGC.

Kinanti, A.A. 2015. Pengembangan Multimedia Interaktif Jaringan Hewan sebagai Suplemen Pembelajaran Biologi di SMA (Skripsi). Semarang: Universitas Negeri Semarang.

Leeson, C.R., T.S. Leeson, \& A.A. Paparo. 1989. Buku Ajar Histologi. Edisi ke-lima. Terj. dari Textbook of Histology. Oleh Siswojo dkk. Jakarta: Penerbit Buku Kedoktean EGC.

McLaughlin, J. S. and Seaquist, S. B. 2008. Using a Virtual Tissue Culture System to Assist Student in Understanding Life at the Cellular Level. The American Biology Teacher 70 (7): 415-420. 
Mescher, Anthony L. 2011. Histologi Dasar Junquiera: Teks dan Atlas. Jakarta: Penerbit Buku Kedokteran EGC.

Moeloek, N. 1994. Sistem Reproduksi Jantan / Pria. Dalam: Syahrum, M.H., Kamaludin, \& A. Tjokrenegoro. 1994. Reproduksi dan Embriologi: Dari Satu Sel menjadi Organisme. Jakarta: Balai Penerbit FKUI.

Nalbandov, A.V. 1990. Fisiologi Reproduksi pada Mamalia dan Unggas. Terj. dari Reproductive Physiology of Mamals and Birds, oleh Keman, S. Jakarta : Penerbit Universitas Indonesia.

Novelina, S., Putra, M.S., Nisa, S., Setijanto, H., 2014. Tinjauan Makroskopik Organ Reproduksi Jantan Musang Luak (Paradoxurus hermaphroditus).

Acta Veterinaria Indonesiana 2 (1): 26-30.

Pearce, Evelyn C. 2005. Anatomi dan Fisiologi untuk Paramedis. Jakarta: Gramedia.

Phadmancanty R.P.L.N., Nugraha R.T.P., Wirdateti. 2013. Organ Reproduksi Jantan Sulawesi Giant Rat (Paruromys dominator). Pusat Penelitian Biologi LIPI. Jurnal Sain Veteriner 31 (1): 102-104.

Rahardjo, Noorhadi. 2011. Catatan Kuliah Atlas dan Peta Navigasi. Yogyakarta: Fakultas Geografi UGM.

Rugh, R. 1968. The Mouse: Its Production and Developmental. Minneapolis: Burgess Publishing Company.

Sadiman, A 2002. Media Pendidikan (Pengertian, Pengembangan dan pemanfaatannya). Jakarta: PT Raja Grafindo Persada.

Smith, J.B. \& Mangkoewidjojo, S. 1988. Pemeliharaan, Pembiakan, dan Penggunaan Hewan Percobaan di Daerah Tropis. Jakarta: UI Press.
Sudjana, Nana dan Ahmad, Rivai. 2007 Media Pembelajaran Bandung: Sinar Baru Algensindo.

Sudjoko, dkk. 2001. Ekologi. Yogyakarta: FMIPA UNY.

Suhardi, Haryono, Sudarmadji. 2007. Analisa Bahan Makanan dan Pertanian. Yoryakarta: Liberti.

Sylvia S. M. 2005. Understanding Human Anatomy \& Physiologi. New York: Mc Graw Hill.

Tarwoto, Ratna Aryani, Wartonah. 2005. Anatomi Fisiologi untuk Mahasiswa Keperawatan. Jakarta: Trans Info Media.

Toelihere, M. R. 1977. Fisiologi Reproduksi pada Ternak. Bandung: Penerbit Angkasa.

Untari, Fuzna S. 2016. Pengembangan Ensiklopedi Keanekaragaman Capung Sungai Oyo sebagai Sumber Belajar untuk Siswa Kelas X SMA/MA. (Skripsi). UIN Sunan Kalijaga Yogyakarta. Yogyakarta.

Utami, Nurul, Boko, Susilo, Welly, Darwis. 2015. Rancang Bangun Media Pembelajaran Biologi SMA Kelas XI Materi Jaringan Hewan Vertebrata $3 D$ berbasis Desktop dan Augmented Reality. Bengkulu: Universitas Bengkulu.

Windle, Wiliam.F. 1976. Textbook of Histology. New York: McGraw-Hill Book Company.

Wulansari, D. L. 2015. Pengembangan Atlas Keanekaragaman Tumbuhan: Euphorbiales, Myrtales, dan Solanales sebagai sarana Identifikasi. Jurnal BioEdu. 4(3): 1030.

Yatim, Wildan. 1990. Histologi. . Bandung: Penerbit Tarsito. 